\title{
Population genetic structure of European hake, Merluccius merluccius
}

\author{
MARÍA INÉS ROLDÁN*†, J OSÉ LUIS GARCÍA-MARÍN†, FRED M. UTTER \& \& \\ CARLES PLA $\dagger$ \\ †Laboratori d'Ictiologia Genètica, Universitat de Girona, Campus Montilivi, E-17071 Girona, Spain and \#University of \\ Washington, School of Fisheries, Box 357980, Seattle, WA-98195-6715, WA, U.S.A.
}

\begin{abstract}
Allozyme analysis of tissue samples of 910 European hake Merluccius merluccius from six North Atlantic Ocean and four Mediterranean Sea locations revealed polymorphism at 21 out of 34 protein-coding loci examined. A major subdivision between Atlantic and Mediterranean collections (mean Nei's genetic distance within regions 0.005 ; between regions 0.014 ) was particularly evident from allelic differences at the $G A P D H-1 *$ and $G R-2 *$ loci. Further population subdivision was indicated within both regions, and gene flow from adjacent Atlantic to proximal Mediterranean populations was suggested by allele frequencies and relevant oceanographic and geological information. The data support present management based on distinct Atlantic and Mediterranean populations and indicate that the population structure within the Atlantic is more complex than the discrete northern and southern stocks proposed by ICES.
\end{abstract}

Keywords: European hake, isozymes, Merluccius merluccius, population subdivision.

\section{Introduction}

The European hake, Merluccius merluccius is a highly sought after species which is widely distributed from the Black Sea through the Straits of Gibraltar and along the Atlantic coast from Morocco to Norway (Svetovidov, 1986). Management of this species has been based on the assumption of the existence of distinct Mediterranean and Atlantic stocks isolated by the Gibraltar channel. This assumption has been mainly supported by morphological data (Cadenat, 1952; Maurin, 1968), but also by preliminary genetic results (Pla et al., 1991). In addition, the International Council for the Exploration of the Sea (ICES) assumes the existence of two stocks within the Atlantic area, one extending northward of $44^{\circ} 30^{\prime}$ and the other southward with the Cape Breton Canyon as the geographical boundary. However, the existence of these two Atlantic stocks is not supported by clear biological evidence (see González-Garcés \& Pereiro, 1994).

This paper examines the population structure of European hake based on six collections from the Atlantic Ocean and four from Mediterranean waters, based on genetic variation at 21 proteincoding loci.

\footnotetext{
*Correspondence. E-mail: dbmrb@xamba.udg.es
}

\section{Materials and methods}

\section{Sampling}

A total of 910 European hake were collected from 10 locations of two major regions (Atlantic Ocean and Mediterranean Sea) (Fig. 1). Except for the

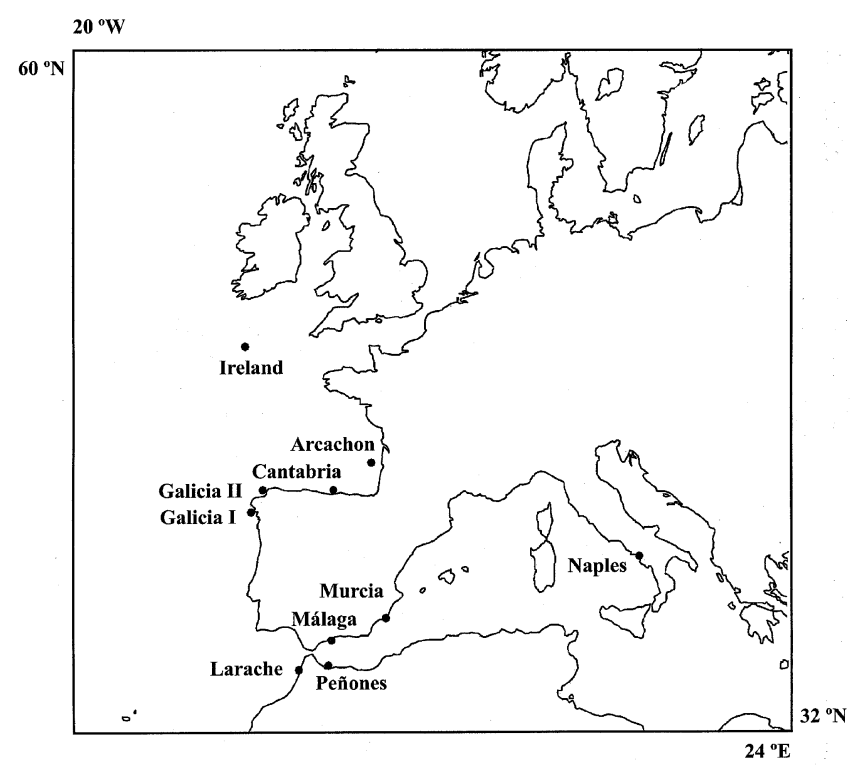

Fig. 1 Geographical locations where European hake were sampled. 
Arcachon, Cantabria and Galicia I and II samples, which were taken from the survey 'Demersales 09/92' of the R/V 'Cornide de Saavedra' (Instituto Español de Oceanografía), unprocessed whole fish (longer than $20 \mathrm{~cm}$ ) were obtained from local fishermen on the date of capture. They were immediately frozen with dry ice and were stored at $-80^{\circ} \mathrm{C}$ prior to electrophoretic analyses.

\section{Electrophoresis}

Tissue extraction, electrophoresis and procedures for visualizing proteins generally followed the methods outlined in Aebersold et al. (1987). Extracts from tissues including eye (E), liver (L) and skeletal muscle (M) were electrophoretically screened for resolution and activity with buffer systems described in García-Marín et al. (1991) (Table 1). Genetic interpretations of these patterns followed principles outlined in Utter et al. (1987). Genetic nomenclature follows Shaklee et al. (1990). Details of allele designation are presented in Roldán (1995).

\section{Data analyses}

Genotypic distributions of all loci were tested for conformance to Hardy-Weinberg expectations using the exact probability test. Gametic associations for all possible pairs of alleles at distinct loci in each population were tested by computing the unbiased composite-linkage disequilibrium $(D)$. Genic differentiation among samples was evaluated by an exact

Table 1 Enzyme systems, loci abbreviations and tissues with strongest expression in European hake

\begin{tabular}{|c|c|c|c|c|}
\hline Enzyme & EC no. & Locus & Tissue & Polymorphic \\
\hline Adenylate kinase & 2.7.4.3 & $A K^{*}$ & M & No \\
\hline Creatine kinase & 2.7.3.2 & $C K^{*}$ & M & No \\
\hline \multirow{4}{*}{ Esterase } & \multirow{4}{*}{ 3.1.1.- } & EST-1* & $\mathrm{M}, \mathrm{E}$ & No \\
\hline & & EST-2* & $\mathrm{M}, \mathrm{E}$ & No \\
\hline & & EST-3* & $\mathrm{M}, \mathrm{E}$ & No \\
\hline & & EST-4* & $\mathrm{M}, \mathrm{E}$ & Yes \\
\hline \multirow[t]{3}{*}{ Glyceraldehyde-3-phosphate dehydrogenase } & \multirow[t]{3}{*}{ 1.2.1.12 } & GAPDH-1* & M & Yes \\
\hline & & GAPDH-2* & $\mathrm{E}$ & No \\
\hline & & GAPDH-3* & $\mathrm{E}$ & No \\
\hline Glycerate dehydrogenase & 1.1.1.29 & $G L Y D H-1 *$ & $\mathrm{~L}$ & Yes \\
\hline Glycerol-3-phosphate dehydrogenase & 1.1.1.8 & $G 3 P D H^{*}$ & $\mathrm{M}$ & Yes \\
\hline \multirow{2}{*}{ Glucose-6-phosphate isomerase } & \multirow{2}{*}{ 5.3.1.9 } & $G P I-1 *$ & M & Yes \\
\hline & & $G P I-2 *$ & $\mathrm{E}$ & Yes \\
\hline \multirow[t]{2}{*}{ Glutathione reductase } & \multirow[t]{2}{*}{ 1.6.4.2 } & $G R-1 *$ & $\mathrm{~L}$ & Yes \\
\hline & & $G R-2 *$ & $\mathrm{~L}$ & Yes \\
\hline \multirow[t]{2}{*}{ Isocitrate dehydrogenase } & \multirow[t]{2}{*}{ 1.1.1.42 } & $I D H P-1 *$ & $\mathrm{M}$ & Yes \\
\hline & & IDHP-2* & $\mathrm{L}, \mathrm{E}$ & Yes \\
\hline \multirow[t]{3}{*}{ L-Lactate dehydrogenase } & \multirow[t]{3}{*}{ 1.1.1.27 } & $L D H-A^{*}$ & M & Yes \\
\hline & & $L D H-B^{*}$ & M & Yes \\
\hline & & $L D H-C^{*}$ & $\mathrm{~L}$ & No \\
\hline Lactoylglutathione lyase & 4.4.1.5 & $L G L *$ & $\mathrm{M}$ & No \\
\hline \multirow[t]{2}{*}{ Malate dehydrogenase } & \multirow[t]{2}{*}{ 1.1.1.37 } & $M D H-2 *$ & $\mathrm{M}$ & No \\
\hline & & $M D H-3 *$ & $\mathrm{M}, \mathrm{L}$ & Yes \\
\hline \multirow{3}{*}{ Malic enzyme (NADP + ) } & \multirow{3}{*}{ 1.1.1.40 } & $M E P-1 *$ & M & Yes \\
\hline & & $M E P-2 *$ & $\mathrm{M}$ & No \\
\hline & & $M E P-3 *$ & $\mathrm{~L}, \mathrm{E}$ & Yes \\
\hline Peptidase-A (Glycyl-Leucine) & 3.4.-.- & $P E P-A^{*}$ & $\mathrm{M}, \mathrm{E}$ & Yes \\
\hline \multirow{2}{*}{ Peptidase-B (Leucyl-Glycyl-Glycine) } & \multirow{2}{*}{ 3.4.-.- } & $P E P-B-1 *$ & $\mathrm{M}, \mathrm{E}$ & Yes \\
\hline & & $P E P-B-2^{*}$ & $\mathrm{M}, \mathrm{E}$ & No \\
\hline Peptidase-S (Leucyl-Tyrosine) & 3.4.-.- & $P E P-S-1 *$ & $\mathrm{M}, \mathrm{E}$ & Yes \\
\hline Phosphogluconate dehydrogenase & 1.1.1.44 & $P G D H^{*}$ & $\mathrm{M}$ & Yes \\
\hline Phosphoglucomutase & 5.4 .2 .2 & $P G M^{*}$ & M & Yes \\
\hline Pyruvate kinase & 2.7.1.40 & $P K-3 *$ & $\mathrm{~L}$ & No \\
\hline Superoxide dismutase & 1.15.1.1 & $S O D^{*}$ & $\mathrm{~L}, \mathrm{E}$ & Yes \\
\hline
\end{tabular}

M, skeletal muscle; L, liver; E, eye. 
probability test. An unbiased estimate of the $P$-value for each locus was obtained using a Markov chain method. All the above calculations were carried out using the population genetic software package GENEPOP and the additional software LINKDOS distributed with it (Raymond \& Rousset, 1995; and references therein). The sequential Bonferroni technique (Rice, 1989) was used to adjust significance levels for multiple simultaneous comparisons.

Genetic differentiation of populations was assessed by $F$-statistics (Wright, 1965). Pairwise multilocus comparisons between samples were calculated by the Cavalli-Sforza and Edwards chord distance (Cavalli-Sforza \& Edwards, 1967). These values were then used to construct a neighbourjoining tree (Saitou \& Nei, 1987). Bootstrap values for trees were calculated from 1000 replications resampling across loci.

\section{Results}

\section{Genetic variation within populations}

We interpreted the banding patterns of 20 enzyme systems to be a reflection of 34 genetic loci (Table 1). Thirteen of the 34 loci were monomorphic, based on the identical phenotypes for all individuals tested. Apparent Mendelian variation was detected for the remaining 21 loci (Table 2). At 11 of these loci, at least one presumed heterozygous individual was found, but with the frequency of the common allele higher than 0.95 in all samples. The remaining 10 variable loci $\left(G A P D H-1^{*}, G P I-1^{*}\right.$, GPI-2*, GR-1*, GR-2*, IDHP-2*, MEP-3*, PEP-B$1^{*}, P E P-S-1^{*}$ and $\left.S O D^{*}\right)$ were regarded as highly polymorphic with frequencies of variant alleles exceeding $5 \%$ in one or more populations. The average proportion of polymorphic loci $(0.05$ criterion) among the 10 collections was $22.1 \%$ and ranged between $14.7 \%$ (Naples) and $32.4 \%$ (Larache). Overall average heterozygosity for all 34 loci was 0.078 and ranged between 0.065 (Naples) and 0.085 (Galicia I).

For all collections, tests were made for HardyWeinberg proportions with all polymorphic loci, and for gametic disequilibrium among the five most highly polymorphic loci; GAPDH-1*, GPI-1*, $G P I-2 *, G R-2 *$ and $S O D^{*}$. No significant departures from expected values $(P<0.05)$ were found for either test.

\section{Genetic variation among populations}

Allele frequency differences among populations (Table 3) were significant over all collections at nine loci (GAPDH-1*, GLYDH-1*, GPI-1*, GPI-2*, $\left.G R-2^{*}, M E P-3^{*}, P E P-S-1^{*}, P G M^{*}, S O D^{*}\right)$. This significant variation is the basis for patterns of relationship and distinction among the collections that emerge through reinspection of Table 2, and tabulations and projections of pairwise measures of genetic variation (Table 4, Fig. 2).

Collections from the Mediterranean and Atlantic basins appear to be differentiated by several criteria, although the distinctions are less clear near the interfacing of the basins. The difference is particularly apparent at $G A P D H-1$ * with no overlapping allele frequencies and a mean difference of 0.256 between groups. A distinction of similar magnitude is evident at $G R-2 * 100$ with a notable exception of the Atlantic collection from Larache, located adjacent to the Mediterranean and having the highest frequency of the $* 100$ allele among all collections. The distribution of rare alleles at $\mathrm{MDH}-3 *$ differs; the allele $* 100$ occurs only in two Atlantic collections, and the allele $* 55$ is restricted to three of the Mediterranean localities.

An Atlantic-Mediterranean division is further indicated by consideration of variation over all loci. The higher gene diversity $\left(F_{\mathrm{ST}}\right.$, Table 3$)$ over all collections (0.054) than measured for Atlantic (0.030) or Mediterranean (0.024) samples further reflects greater genetic heterogeneity between than within basins. Samples from either basin are separated in neighbour-joining clustering (Fig. 2). Notably, the Larache and Peñones samples, respectively, taken in the Atlantic and Mediterranean basins immediately adjacent to the Strait of Gibraltar cluster most closely with one another.

Among the Atlantic samples, the four collections within or adjacent to the Cantabric Sea (Arcachon, Cantabria, Galicia I, Galicia II) comprise an apparent geographical and genetic grouping. Notable distinctions include uniform and nonoverlapping allele frequencies at $M E P-1^{*}, M E P-3^{*}$ and $G R-2 *$ with the remaining localities. At $G R-2 *$, the absence of the $* 93$ allele in these four collections (with one exceptional individual) particularly contrasts with its presence in between eight and 20 individuals in each of the other six collections. The overall similarity of these collections is further reflected in their low genetic distances (ranging from 0.0077 to 0.0127 ) compared to a higher range (0.0128-0.0373) in comparisons with other Atlantic collections (Table 4), and their distinct clustering in Fig. 2.

The allelic distribution among the four Mediterranean collections fits no geographical pattern. Similar allele frequencies at GAPDH-1* and $S O D^{*}$ 
Table 2 Allele frequencies of 21 polymorphic loci for 10 collections of European hake from the Atlantic Ocean and the Mediterranean Sea

\begin{tabular}{|c|c|c|c|c|c|c|c|c|c|c|c|}
\hline \multirow[b]{3}{*}{ Locus } & \multirow[b]{3}{*}{ Allele } & \multicolumn{10}{|c|}{ Sampling Localities $\left(N^{1}\right)$} \\
\hline & & \multicolumn{6}{|c|}{ Atlantic Ocean } & \multicolumn{4}{|c|}{ Mediterranean Sea } \\
\hline & & $\begin{array}{c}\text { Ireland } \\
(125)\end{array}$ & $\begin{array}{c}\text { Arcachon } \\
\quad(57)\end{array}$ & $\begin{array}{c}\text { Cantabria } \\
(84)\end{array}$ & $\begin{array}{l}\text { Galicia II } \\
\text { (61) }\end{array}$ & $\begin{array}{c}\text { Galicia I } \\
\text { (46) }\end{array}$ & $\begin{array}{c}\text { Larache } \\
(100)\end{array}$ & $\begin{array}{c}\text { Málaga } \\
(97)\end{array}$ & $\begin{array}{c}\text { Peñones } \\
\text { (101) }\end{array}$ & $\begin{array}{c}\text { Murcia } \\
(149)\end{array}$ & $\begin{array}{c}\text { Naples } \\
(90)\end{array}$ \\
\hline EST-4* & $\begin{array}{l}* 110 \\
* 100\end{array}$ & 1.000 & $\begin{array}{l}0.991 \\
0.009\end{array}$ & 1.000 & 1.000 & 1.000 & 1.000 & 1.000 & 1.000 & $\begin{array}{l}0.997 \\
0.003\end{array}$ & 1.000 \\
\hline GAPDH-1* & $\begin{array}{l}* 30 \\
* 100\end{array}$ & $\begin{array}{l}0.836 \\
0.164\end{array}$ & $\begin{array}{l}0.825 \\
0.175\end{array}$ & $\begin{array}{l}0.887 \\
0.113\end{array}$ & $\begin{array}{l}0.811 \\
0.189\end{array}$ & $\begin{array}{l}0.837 \\
0.163\end{array}$ & $\begin{array}{l}0.830 \\
0.170\end{array}$ & $\begin{array}{l}0.613 \\
0.387\end{array}$ & $\begin{array}{l}0.723 \\
0.277\end{array}$ & $\begin{array}{l}0.537 \\
0.463\end{array}$ & $\begin{array}{l}0.456 \\
0.544\end{array}$ \\
\hline GLYDH-1* & $\begin{array}{l}* 100 \\
* 150\end{array}$ & $\begin{array}{l}0.992 \\
0.008\end{array}$ & 1.000 & $\begin{array}{l}0.952 \\
0.048\end{array}$ & $\begin{array}{l}0.967 \\
0.033\end{array}$ & $\begin{array}{l}0.967 \\
0.033\end{array}$ & 1.000 & $\begin{array}{l}0.990 \\
0.010\end{array}$ & 1.000 & $\begin{array}{l}0.997 \\
0.003\end{array}$ & $\begin{array}{l}0.994 \\
0.006\end{array}$ \\
\hline$G 3 P D H^{*}$ & $\begin{array}{l}* 100 \\
* 65 \\
* 60\end{array}$ & $\begin{array}{l}0.980 \\
0.020\end{array}$ & $\begin{array}{l}0.974 \\
0.026\end{array}$ & $\begin{array}{l}0.970 \\
0.024 \\
0.006\end{array}$ & $\begin{array}{l}0.984 \\
0.016\end{array}$ & $\begin{array}{l}0.989 \\
0.011\end{array}$ & 1.000 & $\begin{array}{l}0.995 \\
0.005\end{array}$ & $\begin{array}{l}0.960 \\
0.040\end{array}$ & $\begin{array}{l}0.966 \\
0.034\end{array}$ & 1.000 \\
\hline$G P I-1^{*}$ & $\begin{array}{l}* 200 \\
* 100 \\
* 240\end{array}$ & $\begin{array}{l}0.468 \\
0.528 \\
0.004\end{array}$ & $\begin{array}{l}0.535 \\
0.465\end{array}$ & $\begin{array}{l}0.524 \\
0.470 \\
0.006\end{array}$ & $\begin{array}{l}0.336 \\
0.664\end{array}$ & $\begin{array}{l}0.500 \\
0.500\end{array}$ & $\begin{array}{l}0.485 \\
0.510 \\
0.005\end{array}$ & $\begin{array}{l}0.454 \\
0.546\end{array}$ & $\begin{array}{l}0.495 \\
0.505\end{array}$ & $\begin{array}{l}0.436 \\
0.560 \\
0.003\end{array}$ & $\begin{array}{l}0.478 \\
0.516 \\
0.006\end{array}$ \\
\hline$G P I-2 *$ & $\begin{array}{l}* 100 \\
* 125 \\
* 140\end{array}$ & $\begin{array}{l}0.207 \\
0.793\end{array}$ & $\begin{array}{l}0.158 \\
0.842\end{array}$ & $\begin{array}{l}0.232 \\
0.756 \\
0.012\end{array}$ & $\begin{array}{l}0.148 \\
0.844 \\
0.008\end{array}$ & $\begin{array}{l}0.250 \\
0.750\end{array}$ & $\begin{array}{l}0.091 \\
0.909\end{array}$ & $\begin{array}{l}0.031 \\
0.964 \\
0.005\end{array}$ & $\begin{array}{l}0.302 \\
0.698\end{array}$ & $\begin{array}{l}0.272 \\
0.715 \\
0.013\end{array}$ & $\begin{array}{l}0.028 \\
0.966 \\
0.006\end{array}$ \\
\hline$G R-1^{*}$ & $\begin{array}{c}* 100 \\
* 75 \\
* 145\end{array}$ & $\begin{array}{l}0.924 \\
0.052 \\
0.024\end{array}$ & $\begin{array}{l}0.982 \\
0.018\end{array}$ & $\begin{array}{l}0.964 \\
0.006 \\
0.030\end{array}$ & $\begin{array}{l}0.934 \\
0.016 \\
0.049\end{array}$ & $\begin{array}{l}0.957 \\
0.022 \\
0.022\end{array}$ & $\begin{array}{l}0.915 \\
0.060 \\
0.025\end{array}$ & $\begin{array}{l}0.907 \\
0.046 \\
0.046\end{array}$ & $\begin{array}{l}0.950 \\
0.040 \\
0.010\end{array}$ & $\begin{array}{l}0.956 \\
0.020 \\
0.023\end{array}$ & $\begin{array}{l}0.972 \\
0.028\end{array}$ \\
\hline$G R-2 *$ & $\begin{array}{c}* 100 \\
* 110 \\
* 93\end{array}$ & $\begin{array}{l}0.648 \\
0.259 \\
0.193\end{array}$ & $\begin{array}{l}0.518 \\
0.482\end{array}$ & $\begin{array}{l}0.567 \\
0.433\end{array}$ & $\begin{array}{l}0.598 \\
0.393 \\
0.008\end{array}$ & $\begin{array}{l}0.533 \\
0.467\end{array}$ & $\begin{array}{l}0.921 \\
0.037 \\
0.042\end{array}$ & $\begin{array}{l}0.892 \\
0.026 \\
0.082\end{array}$ & $\begin{array}{l}0.855 \\
0.040 \\
0.105\end{array}$ & $\begin{array}{l}0.882 \\
0.042 \\
0.076\end{array}$ & $\begin{array}{l}0.848 \\
0.056 \\
0.096\end{array}$ \\
\hline$I D H P-1 *$ & $\begin{array}{l}* 100 \\
* 75\end{array}$ & $\begin{array}{l}0.996 \\
0.004\end{array}$ & 1.000 & $\begin{array}{l}0.994 \\
0.006\end{array}$ & 1.000 & 1.000 & 1.000 & $\begin{array}{l}0.979 \\
0.021\end{array}$ & 1.000 & $\begin{array}{l}0.997 \\
0.003\end{array}$ & 1.000 \\
\hline$I D H P-2 *$ & $\begin{array}{l}* 100 \\
* 75\end{array}$ & $\begin{array}{l}0.948 \\
0.052\end{array}$ & $\begin{array}{l}0.956 \\
0.044\end{array}$ & $\begin{array}{l}0.946 \\
0.054\end{array}$ & $\begin{array}{l}0.967 \\
0.033\end{array}$ & $\begin{array}{l}0.935 \\
0.065\end{array}$ & $\begin{array}{l}0.945 \\
0.055\end{array}$ & $\begin{array}{l}0.959 \\
0.041\end{array}$ & $\begin{array}{l}0.990 \\
0.010\end{array}$ & $\begin{array}{l}0.940 \\
0.060\end{array}$ & $\begin{array}{l}0.967 \\
0.033\end{array}$ \\
\hline$L D H-A^{*}$ & $\begin{array}{c}* 100 \\
* 215 \\
* 60\end{array}$ & 1.000 & 1.000 & $\begin{array}{l}0.994 \\
0.006\end{array}$ & $\begin{array}{l}0.992 \\
0.008\end{array}$ & 1.000 & 1.000 & 1.000 & 1.000 & 1.000 & 1.000 \\
\hline$L D H-B^{*}$ & $\begin{array}{l}* 100 \\
* 80\end{array}$ & 1.000 & $\begin{array}{l}0.991 \\
0.009\end{array}$ & $\begin{array}{l}0.994 \\
0.006\end{array}$ & $\begin{array}{l}0.992 \\
0.008\end{array}$ & 1.000 & 1.000 & 1.000 & 1.000 & $\begin{array}{l}0.997 \\
0.003\end{array}$ & 1.000 \\
\hline$M D H-3 *$ & $\begin{array}{c}* 80 \\
* 100 \\
* 55\end{array}$ & $\begin{array}{l}0.996 \\
0.004\end{array}$ & 1.000 & $\begin{array}{l}0.994 \\
0.006\end{array}$ & 1.000 & 1.000 & 1.000 & $\begin{array}{l}0.995 \\
0.005\end{array}$ & 1.000 & $\begin{array}{l}0.997 \\
0.003\end{array}$ & $\begin{array}{l}0.994 \\
0.006\end{array}$ \\
\hline$M E P-1^{*}$ & $\begin{array}{l}* 100 \\
* 95\end{array}$ & $\begin{array}{l}0.968 \\
0.032\end{array}$ & $\begin{array}{l}0.991 \\
0.009\end{array}$ & $\begin{array}{l}0.988 \\
0.012\end{array}$ & 1.000 & 1.000 & $\begin{array}{l}0.950 \\
0.050\end{array}$ & $\begin{array}{l}0.964 \\
0.036\end{array}$ & $\begin{array}{l}0.950 \\
0.050\end{array}$ & $\begin{array}{l}0.973 \\
0.027\end{array}$ & $\begin{array}{l}0.972 \\
0.028\end{array}$ \\
\hline$M E P-3^{*}$ & $\begin{array}{l}* 100 \\
* 95\end{array}$ & $\begin{array}{l}0.956 \\
0.044\end{array}$ & 1.000 & 1.000 & 1.000 & 1.000 & $\begin{array}{l}0.940 \\
0.060\end{array}$ & $\begin{array}{l}0.959 \\
0.041\end{array}$ & $\begin{array}{l}0.950 \\
0.050\end{array}$ & $\begin{array}{l}0.943 \\
0.057\end{array}$ & $\begin{array}{l}0.994 \\
0.006\end{array}$ \\
\hline$P E P-A^{*}$ & $\begin{array}{l}* 100 \\
* 108\end{array}$ & $\begin{array}{l}0.984 \\
0.016\end{array}$ & $\begin{array}{l}0.982 \\
0.018\end{array}$ & $\begin{array}{l}0.976 \\
0.024\end{array}$ & $\begin{array}{l}0.975 \\
0.025\end{array}$ & $\begin{array}{l}0.957 \\
0.043\end{array}$ & $\begin{array}{l}0.980 \\
0.020\end{array}$ & $\begin{array}{l}0.964 \\
0.036\end{array}$ & 1.000 & $\begin{array}{l}0.956 \\
0.044\end{array}$ & $\begin{array}{l}0.978 \\
0.022\end{array}$ \\
\hline$P E P-B-1 *$ & $\begin{array}{l}* 100 \\
* 95\end{array}$ & $\begin{array}{l}0.924 \\
0.076\end{array}$ & $\begin{array}{l}0.982 \\
0.018\end{array}$ & $\begin{array}{l}0.958 \\
0.042\end{array}$ & $\begin{array}{l}0.951 \\
0.049\end{array}$ & $\begin{array}{l}0.922 \\
0.078\end{array}$ & $\begin{array}{l}0.900 \\
0.100\end{array}$ & $\begin{array}{l}0.964 \\
0.036\end{array}$ & $\begin{array}{l}0.955 \\
0.045\end{array}$ & $\begin{array}{l}0.966 \\
0.034\end{array}$ & $\begin{array}{l}0.978 \\
0.022\end{array}$ \\
\hline
\end{tabular}

(C) The Genetical Society of Great Britain, Heredity, 81, 327-334. 


\begin{tabular}{|c|c|c|c|c|c|c|c|c|c|c|c|}
\hline \multirow{2}{*}{ Locus } & \multirow{2}{*}{ Allele } & \multicolumn{10}{|c|}{ Sampling Localities $\left(N^{1}\right)$} \\
\hline & & \multicolumn{6}{|c|}{ Atlantic Ocean } & \multicolumn{4}{|c|}{ Mediterranean Sea } \\
\hline$P E P-S-1^{*}$ & $* 100$ & 0.920 & 0.930 & 0.863 & 0.820 & 0.859 & 0.910 & 0.938 & 0.896 & 0.953 & 0.950 \\
\hline \multirow[t]{3}{*}{$P G D H^{*}$} & $* 110$ & 0.996 & 1.000 & 1.000 & 1.000 & 0.989 & 1.000 & 0.995 & 0.995 & 1.000 & 0.989 \\
\hline & $* 120$ & 0.004 & & & & 0.011 & & 0.005 & & & \\
\hline & $* 85$ & & & & & & & & 0.005 & & 0.011 \\
\hline \multirow[t]{2}{*}{$P G M^{*}$} & $* 100$ & 0.996 & 1.000 & 1.000 & 1.000 & 1.000 & 0.995 & 0.995 & 0.995 & 0.990 & 1.000 \\
\hline & $* 120$ & 0.004 & & & & & 0.005 & & & & \\
\hline$S O D^{*}$ & $* 163$ & & & & 0.008 & & & & & & \\
\hline
\end{tabular}

${ }^{1}$ Excepting $N=44$ at $G R-2 *$ for the Ireland collection.

Table $3 F_{\mathrm{ST}}$ analyses at all loci for different groupings of European hake. Probabilities are based on contingency chi-squared analyses

\begin{tabular}{|c|c|c|c|}
\hline \multirow[b]{2}{*}{ Locus } & \multicolumn{3}{|c|}{ Comparison } \\
\hline & Total samples & Atlantic & Mediterranean \\
\hline EST-4* & 0.006 & 0.007 & 0.003 \\
\hline$G A P D H-1^{*}$ & $0.102 * * *$ & 0.004 & $0.056 * * *$ \\
\hline$G L Y D H-1 *$ & $0.347^{* *}$ & $0.017^{*}$ & 0.005 \\
\hline$G 3 P D H^{*}$ & 0.010 & 0.005 & 0.015 \\
\hline$G P I-1^{*}$ & $0.011^{* * *}$ & 0.018 & $0.002 * * *$ \\
\hline$G P I-2 *$ & $0.059 * * *$ & $0.020^{*}$ & $0.092 * * *$ \\
\hline$G R-1^{*}$ & 0.011 & 0.011 & 0.007 \\
\hline$G R-2^{*}$ & $0.154 * * *$ & $0.104 * * *$ & 0.005 \\
\hline IDHP-1* & 0.011 & 0.004 & 0.012 \\
\hline$I D H P-2 *$ & 0.006 & 0.002 & 0.010 \\
\hline$L D H-A^{*}$ & 0.006 & 0.005 & - \\
\hline$L D H-B^{*}$ & 0.005 & 0.004 & 0.003 \\
\hline$M D H-3 *$ & 0.003 & 0.004 & 0.002 \\
\hline$M E P-1 *$ & 0.013 & 0.020 & 0.002 \\
\hline$M E P-3 *$ & $0.025^{* * *}$ & $0.037 * * *$ & 0.001 \\
\hline$P E P-A^{*}$ & 0.007 & 0.004 & 0.012 \\
\hline$P E P-B-1^{*}$ & 0.013 & 0.013 & 0.015 \\
\hline$P E P-S-1 *$ & $0.020 * *$ & 0.015 & 0.007 \\
\hline$P G D H^{*}$ & 0.006 & 0.007 & 0.003 \\
\hline$P G M^{*}$ & $0.004 * * *$ & $0.003 * * *$ & 0.002 \\
\hline$S O D^{*}$ & $0.021^{* *}$ & 0.012 & 0.009 \\
\hline Totals & $0.054 * * *$ & $0.030 * * *$ & $0.024 * * *$ \\
\hline
\end{tabular}

${ }^{*} P<0.05,{ }^{*} P<0.01,{ }^{* * *} P<0.001$.

(C) The Genetical Society of Great Britain, Heredity, 81, 327-334 suggesting groupings of Málaga-Peñones and Murcia-Naples are offset by different relationships indicated at $\mathrm{GPI}-2 *$; indeed, the lowest pairwise genetic distance (0.0099, Table 4) for this group is between Málaga and Naples. The clusterings of Fig. 2 reflect these unclear geographical relationships.

\section{Discussion}

\section{Isolation between Atlantic and Mediterranean samples}

A key to the distinctness between the Atlantic and Mediterranean populations lies in the restriction of migration at the Straits of Gibraltar, separating the Iberian and African tectonic plates (Hopkins, 1985). An even greater barrier at this point existed in the past, with intermittent physical blockages, precluding colonization and gene flow as recently as one million years ago (Maldonado, 1985 and references therein). These blockages resulted in severe ecological distinctions precluding colonization of the Mediterranean by Atlantic species until the Pleistocene (Pérès, 1985). In addition, the recent lowering of sea level by $100-200 \mathrm{~m}$ during Quaternary glaciations resulted in the partial or total closure of the Strait (Bianco, 1990). Most likely, then, the Mediterranean was populated by European hake from the Atlantic within the last million years with a great restriction in gene flow during the Quaternary glaciations. Evidence of such a restriction persists in the separa- 
Table 4 Matrix of the Cavalli-Sforza \& Edwards (1967) chord distance for European hake

\begin{tabular}{|c|c|c|c|c|c|c|c|c|c|c|}
\hline Population & 1 & 2 & 3 & 4 & 5 & 6 & 7 & 8 & 9 & 10 \\
\hline 1 Ireland & - & & & & & & & & & \\
\hline 2 Arcachon & 0.0282 & - & & & & & & & & \\
\hline 3 Cantabria & 0.0252 & 0.0094 & - & & & & & & & \\
\hline 4 Galicia II & 0.0234 & 0.0127 & 0.0090 & - & & & & & & \\
\hline 5 Galicia I & 0.0251 & 0.0102 & 0.0077 & 0.0094 & - & & & & & \\
\hline 6 Larache & 0.0128 & 0.0372 & 0.0373 & 0.0330 & 0.0369 & - & & & & \\
\hline 7 Málaga & 0.0194 & 0.0457 & 0.0482 & 0.0386 & 0.0468 & 0.0120 & - & & & \\
\hline 8 Peñones & 0.0121 & 0.0388 & 0.0408 & 0.0375 & 0.0403 & 0.0138 & 0.0205 & - & & \\
\hline 9 Murcia & 0.0186 & 0.0404 & 0.0432 & 0.0385 & 0.0412 & 0.0188 & 0.0138 & 0.0110 & - & \\
\hline 10 Naples & 0.0306 & 0.0422 & 0.0518 & 0.0414 & 0.0498 & 0.0237 & 0.0099 & 0.0280 & 0.0174 & - \\
\hline
\end{tabular}

tion of Mediterranean and Atlantic populations detected in the present data.

The likelihood of some gene flow between Atlantic and Mediterranean populations since colonization is also indicated by the present data. The smallest genetic distance between Larache (Atlantic) and any other sample (0.0120) is with adjacent Málaga in the western Mediterranean (Table 4). A similarly small chord distance (0.0138) separates Larache and Peñones, adjacent from the African side of Gibraltar. This geographical and genetic proximity is reflected by intermediate frequencies at, for instance, $G A P D H-1 *$ and $S O D^{*}$, relative to other Mediterranean samples, and by the clustering in Fig. 2. The absence of detectable genotypic or gametic disequilibria coupled with still distinct allelic profiles for these three collections at, for instance, $G A P D H-1 *$ and $G P I-2 *$ suggests that any gene flow is an intermittent rather than a continual process.

Any gene exchanges implied by these relationships were presumably in one direction, from the Atlantic

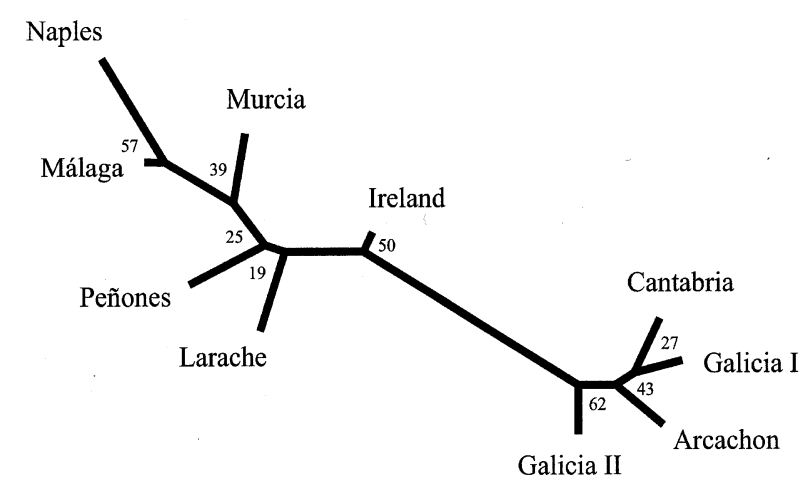

Fig. 2 Unrooted neighbour-joining tree constructed from the Cavalli-Sforza and Edwards chord distance values of Table 4. The numbers refer to the percentage of 1000 bootstrap replications. to the Mediterranean, given the present flow of water between these basins. The most likely time for migration is during the extended pelagic juvenile phase (well into the second year) when young fish are at the mercy of prevailing currents (e.g. Inada, 1981). During this time, the flow of upper waters is from the Atlantic to the Mediterranean (Bouchet \& Taviani, 1992; Parrilla \& Kinder, 1992; Rubin et al., 1992; Minas \& Minas, 1993).

\section{Possible Atlantic substructuring}

As indicated above, the Larache sample is relatively different from others of the Atlantic and close in genetic distance to the adjacent western Mediterranean collections (Table 4). This sample may represent a subgroup at the southern extremity of the species in the Atlantic Ocean.

Another possible distinction is the relative homogeneity noted among the four Cantabrian Sea samples (Tables 2 and 4) along a contiguous $1000 \mathrm{~km}$ length (Fig. 1). Should further sampling confirm a population unit within this area, additional substructuring to the north is suggested by the distinction of the Ireland sample (primarily from the $G R-2 * 93$ allele) which would not correspond to the ICES-proposed northern and southern stocks.

\section{Comparisons with other species}

The European hake, like many marine species, is not strongly subdivided genetically (e.g. Ward et al., 1994). The primary basis for this restricted degree of subdivision appears to lie primarily in the reduction of barriers to gene flow when contrasted with anadromous and freshwater fishes. Nevertheless, differing levels of genetic subdivision have been identified among marine species and related to differences such as reproductive strategies,

(c) The Genetical Society of Great Britain, Heredity, 81, 327-334. 
ecological restrictions and early life histories (Waples, 1987).

Hake, as well as gadoids in general, tend to follow other highly fecund and populous species with pelagic early life histories in their rather modest levels of subdivision. No subdivision was detected in a rather extensive survey of two species of South African hake, M. capensis and M. paradoxus (Grant et al. 1987). A study of M. productus (Utter \& Hodgins, 1971) revealed two distinct subgroups, one extending along the Pacific coast from Mexico to Canada and the other restricted to the adjacent inland marine areas of Puget Sound (U.S.A.) and Straits of Georgia (Canada). A complex structure has been observed between $M$. hubbsi populations from the San Jorge Gulf and those from other areas of the Argentinian continental shelf (Roldán, 1991).

Using 24 putative gene loci, slight genetic differences among Atlantic and Mediterranean populations have been detected in the clupeoid fish Engraulis encrasicolus (Bembo et al., 1996). A major genetic break in allozyme frequencies (Quesada et al., 1995b) and mtDNA haplotypes (Quesada et al., 1995a) between Atlantic and Mediterranean populations of the mussel Mytilus galloprovincialis has been detected in the east side of the Alborán Sea (Almeria-Orán oceanographic front). Both studies clearly fit with the distinction between Mediterranean and Atlantic populations of European hake, and demonstrate the passive dispersal of pelagic larvae of marine species through the Straits of Gibraltar (see also Bouchet \& Taviani, 1992).

The possibility of selection affecting one or more of the loci used in the present investigation cannot be excluded. However, the common geological and oceanographic attributes underlying the detection of distinct distributions of diverse species common to the Mediterranean and Atlantic basins by allozyme markers are consistent with these markers primarily reflecting the evolutionary forces of drift and migration. Thus we consider the assumption of selective neutrality to be warranted in applying the present set of polymorphic loci in future studies of Atlantic hake.

\section{Management implications}

This survey represents a useful but limited snapshot of population structure of Atlantic hake. More extended sampling in both the Mediterranean and Atlantic basins is needed both to check temporal stability among the areas sampled as well as to obtain further insights from broader and more detailed samplings. The clearest management impli- cation from this study is the genetic validation of the long-standing policy that has assumed isolation between the Mediterranean and Atlantic populations (Cadenat, 1952). This policy has been based on the assumption of genetic isolation imposed by ecological differences existing on either side of the Straits of Gibraltar, as well as on morphological differences observed between Mediterranean and Atlantic hake (revised in Gonzalez-Garcés \& Pereiro, 1994). Management within the Mediterranean is complicated by apparent migration from the Atlantic in the west and by uncertainty regarding population structure in other areas. Until greater clarification is obtained, a conservative strategy is warranted based on assumed isolation between geographically restricted regions.

As indicated above, present management of Atlantic populations, based on two distinct 'northern' and 'southern' stocks, requires modification. The distinction of the Larache collection justifies separate management of 'southern' stocks. However, based on the apparent distinction of Cantabrian and Irish collections and the absence of sampling from more northern areas, multiple subgroups may exist, each requiring management as a separate entity. The definitive number and geographical extension of the stocks in this area must await an adequate sampling and genetic analysis throughout the species range in the Atlantic Ocean.

\section{Acknowledgements}

We thank L. Manzueto, J. Pereiro and A. Ramos for their help in collecting samples and Stewart Grant for useful comments on the manuscript. M.I.R. was supported by a postgraduate fellowship from the Agencia Española de Cooperación Internacional. This work was partially supported by agreement 160719 with Instituto Español de Oceanografía.

\section{References}

AEBERSold, P. B., WinANS, G. A., TEEL, D. J., Miller, G. B. AND UTTER, F. M. 1987. Manual for starch gel electrophoresis: a method for detection of genetic variation. NOAA Technical Report, NMFS, 61, 1-19.

BEMBO, D. G., CARVAlHO, G. R., CINGOLANI, N. AND PITCHER, T. J. 1996. Electrophoretic analysis of stock structure in Northern Mediterranean anchovies, Engraulis encrasicolus. ICES J. Mar. Sci., 53, 115-128.

BIANCO, P. G. 1990. Potential role of the palaeohistory of the Mediterranean and Paratethys basins on the early dispersal of Euro-Mediterranean freshwater fishes. Ichthyol. Exploration Freshwater, 1, 167-184. 
Bouchet, P. AND taviani, M. 1992. The Mediterranean deep-sea fauna: pseudopopulations of Atlantic species? Deep-sea Res., 39, 169-184.

CADENAT, J. 1952. Note au sujet des merlus de la région de Dakar. J. Cons. int. Explor. Mer, 18, 231.

CAVAlli-SFORZA, L. L. AND EDWARdS, A. w. F. 1967. Phylogenetic analysis: models and estimation procedures. Evolution, 32, 550-570.

GARCíA-MARÍn, J. L., JORDE, P. E., RYMAN, N., UTTER, F. AND PLA, C. 1991. Management implications of genetic differentiation between native and hatchery populations of brown trout (Salmo trutta) in Spain. Aquaculture, 95, 235-249.

GONZÁleZ-GARCÉs, A. AND PEREIRO, F. J. (eds). 1994. The Present State of Knowledge of Hake Populations Which Live on the Continental Shelf of the Atlantic and Mediterranean Parts of the European Union, with Special Attention to the Iberian Peninsula. Privately published, Vigo, Spain.

GRANT, w. S., LESLIE, R. W. AND BECKER, I. I. 1987. Genetic stock structure of the southern African hakes Merluccius capensis and M. paradoxus. Mar. Ecol. Prog. Ser., 41, 9-20.

HOPKINS, т. s. 1985. Physics of the sea. In: Margalef, R. (ed.) Western Mediterranean, pp. 102-127. Pergamon Press, London.

InADA, T. 1981. Studies on the Merlucciid fish. Bull. Far Seas Fish Res. Laboratory, Shimizu, Japan, 18, 1-172.

MALDONADO, A. 1985. Evolution of the Mediterranean basins and a reconstruction of the Cenozoic palaeoceanography. In: Margalef, R (ed.) Western Mediterranean, pp. 18-61. Pergamon Press, London.

MAURIN, C. 1968. Les merlus des côtes nord et nord-ouest d'Afrique (Atlantique et Méditerranée). Ph.D. Thesis, Université de Nancy, France.

MINAS, H. J. AND MINAS, M. 1993. Influence du détroit de Gibraltar sur le biogéochimie de la Méditerranée et du proche Atlantique. Ann. l'Institut océanogr., 69, 203-214.

PARRILlA, G. AND KINDER, T. H. 1992. The physical oceanography of the Alborán sea. Reports in Meteorol. Oceanography, 40, 143-184.

PÉRÈs, J. M. 1985. History of the Mediterranean biota and the colonization of the depth. In: Margalef, R. (ed.) Western Mediterranean, pp. 200-234. Pergamon Press, London.

PlA, C., VIlA, A. AND GARCíA-MARÍN, J. L. 1991. Différentiation de stocks de merlu (Merluccius merluccius) par l'analyse génétique: comparation de plusiers populations méditerranéennes et atlantiques du littoral espagnol. FAO, Rapport sur les Pêches, 447, 87-93.

QUESADA, H., BEYNON, C. M. AND SKIBINSKI, D. O. F. 1995a. A mitochondrial DNA discontinuity in the mussel Mytilus galloprovincialis Lmk: pleistocene vicariance biogeography and secondary intergradation. Mol. Biol.
Evol., 12, 521-524.

QuesadA, H., ZAPATA, C. AND Alvarez, G. 1995b. A multilocus allozyme discontinuity in the mussel Mytilus galloprovincialis: the interaction of ecological and life-history factors. Mar. Ecol. Prog. Ser., 116, 99-115.

RAYMOND, M. AND ROUSSET, F. 1995. GENEPOP (ver. 1.2): A population genetics software for exact test and ecumenicism. J. Hered., 86, 248-249.

RICE, W. R. 1989. Analyzing tables of statistical tests. Evolution, 43, 223-225.

ROLDÁN, M. I. 1991. Enzymatic polymorphisms in the Argentinian hake, Merluccius hubbsi Marini, of the Argentinian continental shelf. J. Fish Biol., 39 (Suppl. A), 53-59.

ROLDÁN, M. I. 1995. Relaciones filogenéticas en el género Merluccius y estructura genética poblacional en la merluza argentina (Merluccius hubbsi) y la merluza europea (M. merluccius). Ph.D. Thesis, University of Girona, Spain. Tesis microfilm ISBN 84-88762-453.

RUBÍN, J. P., GIL, J., RUIZ, J., CORTÉS, M. D., JIMÉNEZGÓMEZ, F., PARADA, M. ET $A L$. 1992. La distribución ictioplanctónica y su relación con parámetros físicos, químicos y biológicos en el sector norte del Mar de Alborán, en Julio de 1991 (Resultados de la campaña 'ictio.alborán 0791'). IEO, Informe Técnico, no. 139.

SAITOU, N. AND NEI, M. 1987. The neighbor-joining method: a new method for reconstructing phylogenetic trees. Mol. Biol. Evol., 4, 406-425.

SHAKLEE, J. B., ALLENDORF, F. W., MORIZOT, D. C. AND WHITT, G. S. 1990. Gene nomenclature for proteincoding loci in fish. Trans. Am. Fish. Soc., 119, 2-15.

svetovidov, A. N. 1986. Merluccidae. In: Whitehead, P. J. P., Bauchot, M. L., Hureau, J. C., Nielsen, J. \& Tortonese, E (eds) 1986. Fishes of the North-eastern Atlantic and the Mediterranean, Vol. II, pp. 677-678. UNESCO, Paris.

UTTER, F. M. AND HODGINS, H. O. 1971. Biochemical polymorphisms in the Pacific hake (Merluccius productus). Conseil international pour l'exploitation de la mer. Extrait du rapports et proces verbaux, 161, 87-89.

UTTER, F. M., AEBERSOLD, P. AND WINANS, G. 1987. Interpreting genetic variation detected by electrophoresis. In: Ryman, N. and Utter, F. M. (eds) Population Genetics and Fishery Management, pp. 21-45. University of Washington Press, Seattle, WA.

WAPLES, R. S. 1987. A multispecies approach to the analysis of gene flow in marine shore fishes. Evolution, 41, $385-400$.

WARD, R. D., WOODWARK, M. AND SKIBINSKI, D. O. F. 1994. A comparison of genetic diversity levels in marine, freshwater, and anadromous fishes. J. Fish Biol., 44, 213-232.

WRIGHT, S. 1965. The interpretation of population structure by $F$-statistics with special regard to systems of mating. Evolution, 19, 395-420. 